Short communication

\title{
Method for simple and rapid concentration of Zika virus particles from infected cell-culture supernatants
}

\author{
Vaea Richard ${ }^{\mathrm{a}, \mathrm{b}, *}$, Maite Aubry ${ }^{\mathrm{a}, \mathrm{b}}$ \\ a Institut Louis Malardé, PO Box 30, 98713 Papeete, French Polynesia \\ ${ }^{\mathrm{b}}$ Aix Marseille Univ, IRD, AP-HM, SSA, VITROME, IHU-Méditerranée Infection, Marseille, France
}

\section{A R T I C L E I N F O}

\section{Keywords:}

Zika

Viral stock

Ultrafiltration

Concentration

Centrifugal filter device

\begin{abstract}
A B S T R A C T
Experimental studies on Zika virus (ZIKV) may require improvement of infectious titers in viral stocks obtained by cell culture amplification. The use of centrifugal filter devices to increase infectious titers of ZIKV from cellculture supernatants is highlighted here. A mean gain of $2.33 \pm 0.12 \log _{10} \mathrm{DICT}_{50} / \mathrm{mL}$ was easily and rapidly obtained with this process. This efficient method of ultrafiltration may be applied to other viruses and be useful in various experimental studies requiring high viral titers.
\end{abstract}

The globalization of Zika virus (ZIKV; Flavivirus genus, Flaviviridae family) led to a high number of experimental studies during the past years. Experiments may require viral stocks with high concentrations that cannot always be obtained by cellular amplification alone. Different methods such as ultracentrifugation over a density gradient, pressurized filtration or polyethylene glycol precipitation are commonly used to concentrate virus (Chu and Dornburg, 1997; Coelho et al., 2017; Reiser et al., 1996; Russell et al., 2007; Saha et al., 1994; Wunner and Pringle, 1976). Such processes are time-consuming (up to several days) and important losses in infectivity may occur (as much as 99\% loss) (Burns et al., 1993; Chu and Dornburg, 1997; Russell et al., 2007; Saha et al., 1994). A convenient process of ultrafiltration using centrifugal filter devices (CFD) to highly concentrate ZIKV from infected cell-culture supernatants is reported here.

Infected cell-culture supernatants were obtained by amplification of ZIKV (strain PF13/251013-18, GenBank accession number KX369547) on C6/36 or Vero-76 cells (ATCC CRL-1660 and CRL-1587 respectively, USA) as previously described (Aubry et al., 2016; Richard et al., 2015). Supernatants were centrifuged at $4{ }^{\circ} \mathrm{C}$ at $3200 \times g$ for $10 \mathrm{~min}$ to pellet cells in suspension, and were pre-filtrated using $0.22 \mu \mathrm{m}$ filter units (Nalgene, USA) to prevent clogging of the CFD filter and facilitate the ultrafiltration step. Samples of supernatants were collected and stored at $-80^{\circ} \mathrm{C}$ with foetal bovine serum at a dilution of $1: 5$. Clarified cellculture supernatants were then physically concentrated using Centricon Plus-70 CFD (Millipore, Germany) with a membrane pore size of $10 \mathrm{~nm}$ (100K NMWL), following the manufacturers' recommendations to use three- to six-fold lower pore size than the target molecules. Briefly, the CFD was loaded with $70 \mathrm{~mL}$ of supernatant and centrifugation was performed at $4^{\circ} \mathrm{C}$ at $3200 \times g$ for $25-45 \mathrm{~min}$, until approximately $250 \mu \mathrm{L}$ of concentrate of ZIKV-infected supernatant was achieved in the filter core of the CFD. Then the CFD was inverted and centrifugation at $1000 \times g$ was performed during $2 \mathrm{~min}$ at $4{ }^{\circ} \mathrm{C}$ to recover the concentrate. The concentrate was stored at $-80^{\circ} \mathrm{C}$ with foetal bovine serum at a dilution of 1:5 until use.

ZIKV infectious titers were determined in samples collected before and after concentration by inoculation of 10 -fold dilutions of each sample on Vero cells in 96-wells plates. Following 6 days of incubation at $37{ }^{\circ} \mathrm{C}$ in an atmosphere of $5 \% \mathrm{CO}_{2}$, cells were fixed on the plates with cold acetone diluted at 3:4 in phosphate-buffered saline buffer (PBS; Biomérieux, France) for $10 \mathrm{~min}$. Indirect immunofluorescence assay was subsequently performed to detect ZIKV-infected cells using antiflavivirus mouse antibodies 4G2 (Absolute antibody, UK) diluted 1:50 in PBS, then fluorescein isothiocyanate-conjugated goat anti-mouse secondary antibodies (Life technologies, USA) diluted 1:50 in PBS with Evans blue. Wells with ZIKV-positive cells were enumerated for each dilution, and the method of Reed and Muench was used to calculate viral titers in $50 \%$ tissue culture infectious dose $\left(\mathrm{TCID}_{50} / \mathrm{mL}\right.$ ) (Reed and Muench, 1938). Statistical analyses were conducted using the ShapiroWilk test to check normality, and the paired t-test to compare viral titers before and after concentration (Graph Pad Prism software, USA).

Seven CFD-concentration trials were conducted in the context of previous studies (Richard et al., 2017, 2016) using C6/36 (trials 1-2) and Vero-76 (trials 3-7) cell-culture supernatants. For each trial, four CFD were simultaneously used and viral concentrates were pooled to obtain a final volume of about $1 \mathrm{~mL}$. ZIKV titrations were performed at the time of previous studies for samples from C6/36 amplification and

\footnotetext{
* Corresponding author at: Institut Louis Malardé, PO Box 30, 98713 Papeete, French Polynesia.

E-mail address: vrichard@ilm.pf (V. Richard).
} 
Table 1

ZIKV titers in infected cell-culture supernatants before (starting titers) and after (final titers) concentration with Centricon Plus-70 centrifugal filter devices.

\begin{tabular}{llll}
\hline Experimental assay & $\begin{array}{l}\text { Starting ZIKV } \\
\operatorname{titer}^{\mathrm{a}}\left(\log _{10}\right. \\
\left.\text { TCID }_{50} / \mathrm{mL}\right)\end{array}$ & $\begin{array}{l}\text { Final ZIKV titer } \\
\left(\log _{10} \mathrm{TCID}_{50} /\right. \\
\mathrm{mL})\end{array}$ & $\begin{array}{l}\text { Gain in ZIKV titer } \\
\left(\log _{10} \mathrm{TCID}_{50} / \mathrm{mL}\right)\end{array}$ \\
\hline Trial 1 & 6.50 & 8.60 & 2.10 \\
Trial 2 & 6.50 & 9.00 & 2.50 \\
Trial 3 & 3.25 & 5.75 & 2.50 \\
Trial 4 & 3.25 & 5.36 & 2.11 \\
Trial 5 & 4.64 & 7.50 & 2.86 \\
Trial 6 & 4.64 & 6.88 & 2.24 \\
Trial 7 & 4.50 & 6.50 & 2.00 \\
Mean gain & - & - & 2.33 \\
\hline
\end{tabular}

Cell-culture supernatants used for trials were obtained from C6/36 (trials 1-2) and Vero76 (trials 3-7) cultures infected with ZIKV. In each trial, $280 \mathrm{~mL}$ of supernatant were divided into four centrifugal filter devices and concentrated by ultrafiltration to obtain a final pooled-volume of approximately $1 \mathrm{~mL}$. ZIKV, Zika virus.

${ }^{a}$ Discrepancies between C6/36 and Vero starting titers were due to different storage durations.

one year later for samples from Vero amplification. ZIKV infectious titers in samples collected before the concentration step (starting ZIKV titers) consisted in values ranging from 3.25 to $6.50 \log _{10} \mathrm{TCID}_{50} / \mathrm{mL}$ (Table 1). After CFD-concentration, viral titers (final ZIKV titers) were significantly increased $(\mathrm{p}<0.0001)$ with values between 5.36 and $9.00 \log _{10} \mathrm{TCID}_{50} / \mathrm{mL}$. The gain (final titer subtract starting titer) obtained with CFD-concentration varied from 2.00 to $2.86 \log _{10} \mathrm{TCID}_{50} /$ $\mathrm{mL}$ corresponding to a mean gain of $2.33 \pm 0.12 \log _{10} \mathrm{TCID}_{50} / \mathrm{mL}$ (mean \pm standard error).

The ultrafiltration method used here allowed to easily and rapidly obtain samples with higher concentrations of ZIKV from infected cellculture supernatants. Concentrations of cell-culture supernatants by ultrafiltration process have been performed for several retroviruses (Chu and Dornburg, 1997; Reiser, 2000; Reiser et al., 1996; Saha et al., 1994) but only few studies have used this method for arthropod-borne viruses (arboviruses), and usually as an additional step to another process such as ultracentrifugation with a sucrose gradient or pressurized filtration systems to obtain purified virus (Coelho et al., 2017; Huang et al., 2008; Russell et al., 2007). As demonstrated here for ZIKV, in a previous study for dengue virus (Richard et al., 2015), and as also observed for chikungunya virus (personal data), viral titers were greatly increased by $2 \log _{10}$ using CFD, confirming that this method is effective for different arboviruses. Moreover, this ultrafiltration method does not require the addition of chemicals, thus enabling the use of the concentrates for both in vitro and in vivo studies. Indeed, ZIKV concentrates obtained with the CFD-ultrafiltration process have been successfully used in different kinds of studies including vector competence experiments (Richard et al., 2017, 2016) and evaluation of inactivation processes in the transfusion field (Aubry et al., 2016; Laughhunn et al.,
2017; Santa Maria et al., 2017). This convenient CFD-ultrafiltration approach may be applied to other viruses and may be useful in various experimental studies requiring high viral titers.

\section{Funding}

This research did not receive any specific grant from funding agencies in the public, commercial, or not-for-profit sectors.

\section{References}

Aubry, M., Richard, V., Green, J., Broult, J., Musso, D., 2016. Inactivation of Zika virus in plasma with amotosalen and ultraviolet A illumination. Transfusion 56, 33-40. http://dx.doi.org/10.1111/trf.13271.

Burns, J.C., Friedmann, T., Drievert, W., Burrascano, M., Yee, J.K., 1993. Vesicular stomatitis virus $\mathrm{G}$ glycoprotein pseudotyped retroviral vectors: concentration to very high titer and efficient gene transfer into mammalian and nonmammalian cells. Proc. Natl. Acad. Sci. U. S. A. 90, 8033-8037.

Chu, T.H., Dornburg, R., 1997. Toward highly efficient cell-type-specific gene transfer with retroviral vectors displaying single-chain antibodies. J. Virol. 71, 720-725.

Coelho, S.V.A., Neris, R.L.S., Papa, M.P., Schnellrath, L.C., Meuren, L.M., Tschoeke, D.A., Leomil, L., Verçoza, B.R.F., Miranda, M., Thompson, F.L., Da Poian, A.T., Souza, T.M.L., Carneiro, F.A., Damaso, C.R., Assunção-Miranda, I., de Arruda, L.B., 2017. Development of standard methods for Zika virus propagation, titration, and purification. J. Virol. Methods 246, 65-74. http://dx.doi.org/10.1016/j.jviromet.2017. 04.011.

Huang, K., Lin, Y., Liu, H., Yeh, T., Liu, C., Lei, H., 2008. Generation of anti-platelet autoantibody during dengue virus infection. Am. J. Infect. Dis. 4, 50-59.

Laughhunn, A., Santa Maria, F., Broult, J., Lanteri, M.C., Stassinopoulos, A., Musso, D., Aubry, M., 2017. Amustaline (S-303) treatment inactivates high levels of Zika virus in red blood cell components. Transfusion 57, 779-789. http://dx.doi.org/10.1111/trf. 13993.

Reed, L.J., Muench, H., 1938. A simple method of estimating fifty per cent endpoints. Am. J. Epidemiol. 27, 493-497.

Reiser, J., 2000. Production and concentration of pseudotyped HIV-1- based gene transfer vectors. Gene Ther. 7, 910-913.

Reiser, J., Harmison, G., Kluepfel-Stahl, S., Brady, R.O., Karlsson, S., Schubert, M., 1996. Transduction of nondividing cells using pseudotyped defective high-titer HIV type 1 particles. Proc. Natl. Acad. Sci. U. S. A. 93, 15266-15271.

Richard, V., Paoaafaite, T., Cao-Lormeau, V.-M., 2017. Acquittal of Culex quinquefasciatus in transmitting Zika virus during the French Polynesian outbreak. Acta Trop. 173, 200-201. http://dx.doi.org/10.1016/j.actatropica.2017.04.036.

Richard, V., Paoaafaite, T., Cao-Lormeau, V.-M., 2016. Vector competence of French Polynesian Aedes aegypti and Aedes polynesiensis for Zika virus. PLoS Negl. Trop. Dis. 10, e0005024. http://dx.doi.org/10.1371/journal.pntd.0005024.

Richard, V., Viallon, J., Cao-Lormeau, V.-M., 2015. Use of centrifugal filter devices to concentrate dengue virus in mosquito per os infection experiments. PLoS One 10, e0138161. http://dx.doi.org/10.1371/journal.pone.0138161.

Russell, B.J., Velez, J.O., Laven, J.J., Johnson, A.J., Chang, G.J., Johnson, B.W., 2007. A comparison of concentration methods applied to non-infectious flavivirus recombinant antigens for use in diagnostic serological assays. J. Virol. Methods 145, 62-70. http://dx.doi.org/10.1016/j.jviromet.2007.05.008.

Saha, K., Lin, Y.C., Wong, P.K., 1994. A simple method for obtaining highly viable virus from culture supernatant. J. Virol. Methods 46, 349-352.

Santa Maria, F., Laughhunn, A., Lanteri, M.C., Aubry, M., Musso, D., Stassinopoulos, A., 2017. Inactivation of Zika virus in platelet components using amotosalen and ultraviolet A illumination. Transfusion 57, 2016-2025. http://dx.doi.org/10.1111/trf. 14161.

Wunner, W.H., Pringle, C.R., 1976. Respiratory syncytial virus proteins. Virology 73, $228-243$. 